\title{
SOCIAL CAPITAL AS A STIMULANT FOR THE DEVELOPMENT OF ENTERPRISES IN THE PODKARPACKIE PROVINCE
}

\author{
Bogusław Ślusarczyk, Full Professor'; Bernadetta Dziura, PhD² \\ ${ }^{1}$ Faculty of Economics, University of Rzeszów \\ ${ }^{2}$ Institute of Economics and Management, State High Technical and Economic School in Jarosław
}

\begin{abstract}
Social capital is one of the essential elements of an enterprise's development. Enterprises with a high level of social capital, due to the smooth flow of information, are predisposed to achieve higher innovation, gaining an advantage over competitors (Przybysz, 2011). The social capital affects the creation of the unique value of an enterprise, mainly through the structures of the connections network, social and cultural norms as well as trust (Dziura, 2016). Nowadays, it is analysed at various levels and in varying degrees, also in relation to territorial systems, including the provincial level. The present paper is an attempt to analyse and describe the impact of social capital on development of selected enterprises in the Podkarpackie province. Authors of the article, due to the conducted surveys, application of statistical methods and analysis of financial reports, aim at presenting the effects of investing in social capital.
\end{abstract}

Key words: social capital, intellectual capital, enterprise, development JEL codes: 015, 034

\section{INTRODUCTION}

The 21 st century, called the era of globalization and knowledge, is a time of intense changes resulting mainly from the growing availability of information. These changes force enterprises to be ready to constantly develop under the dictation of a changing environment, cause the need to develop the adaptive abilities and introduce new solutions adjusted to the emerging threats and opportunities.

Contemporary management concepts direct the interest of enterprises to human resources, treating them as the most important capital necessary for development of the enterprise. To ensure functioning in a changing and competitive environment, each en- terprise should build the path to success, increasing the value of social capital. The term social capital is interpreted by representatives of particular fields of science (sociology, management, economics) as: social norms, ability to cooperate, trust and credibility, competences and skills, as well as knowledge and experience (Gagacka, 2008).

Paying attention to social capital results primarily from its significant impact on growth, and in consequence, on the competitive advantage of a company on the regional market. Enterprises that want to develop, survive and generate profits are forced to systematically create social capital and manage it effectively. In the conditions of growing competition, enterprises that are focused on continuous development and improv-

\footnotetext{
${ }^{1}$ Corresponding author: al. Rejtana 16c, 35-001 Rzeszów, Poland, boguslaw.slusarczyk@gmail.com, +4817 87217

${ }^{2}$ Corresponding author: Czarnieckiego 16,37-700 Jarosław, Poland, benia.dziura@wp.pl, +4816 6244640
} 
ing their competitiveness through appropriate management of intellectual capital - especially social capital, have chances for further development and survival.

\section{SOCIAL CAPITAL AS AN ELEMENT OF INTELLECTUAL CAPITAL}

The processes of globalization have increased interest and directed the attention of practitioners and scientists to the role of intellectual capital in creating and achieving a competitive position on a market. Intellectual capital has existed in enterprises for a long time, but it is only in recent years that we have experienced the phenomenon of its discovery and use in creating an enterprise value.

Human capital has become a central category among the development factors of modern enterprises. The most important feature of human capital is its inseparable connection with the human person. It is not possible to separate a man from his capital. Therefore, the success of an enterprise depends on the 'knowledge workers' employed in it, on their innovativeness and the ability to identify opportunities, on the speed of action, on the possession of information about clients and business environment. It is very important to create organizational conditions for creating and using the knowledge in the enterprise.

A growing role of intangible values in management prompts to look for factors determining the development of the enterprise, and intangible values inherent in social capital stimulate competition, entrepreneurship and thus the competitiveness of individuals and enterprises (Gagacka, 2008).

Representatives of particular science fields interpret social capital in their own way using language specific to a given field. It is possible to indicate some of the most frequently mentioned elements of it: networks and social structure, social norms, ability to cooperate, cooperation and ability to organize, convince, value - including trust and credibility, competences and skills, as well as knowledge and experience (Gagacka, 2008).

Social capital is a very important resource of an enterprise, enabling the achievement of goals that without its involvement would not even be visible. It follows from the above that social capital increases the willingness to introduce new and develop their existing activities in enterprises. It becomes important to pay attention to the role of social capital in the enterprise management process, its accumulation allows to use the existing enterprise resources and to establish such combinations that create new dimension of resources, thus creating a new company value. Social capital not only contributes to the creation of new value for enterprises, but also participates in the management of this value by acting as a relay of good practices and corporate behaviour - it affects the enterprise making it more flexible and adapting to the changing environment.

Assets that create intellectual capital have an increasing share in the development and creation of the market value of an enterprise. Knowledge of what constitutes the essence of intellectual capital and how it is used in an enterprise gives managers the opportunity to better manage these assets and increase the attractiveness of the enterprise for potential investors (Dziura, 2016).

It should be emphasized that intellectual capital is always based on human capital. The distinction of constituent elements in the concept of intellectual capital, however, emphasizes that although people (human capital) create knowledge, only through interactions between them (social capital), the scope of knowledge is increased, and as a result, institutionalized knowledge belonging to the enterprise (organizational capital) arises. At the end of this process, knowledge becomes a quasi-public benefit (databases, standards, customs, patterns), recognized in a given enterprise as a standard, the dissemination of which allows employees to improve their individual effectiveness.

Mutual relations between components of intellectual capital should be cared for in the process of social capital management, which will allow for a more effective use of intellectual resources in order to more effectively develop and maintain the enterprise on regional market.

\section{SOCIAL CAPITAL IN SELECTED ENTERPRISES OF PODKARPACKIE PROVINCE - STUDY RESULTS}

To assess the extent to which intellectual capital affects the development and competitiveness of selected enterprises in the Podkarpackie province, the 
research was carried out in 400 selected enterprises ${ }^{1}$. Statistical method was used for the analysis of the obtained data - Pearson's $\chi^{2}$ (chi square) test for the independence of features.

Statistical processing of data obtained from the survey was carried out with the help of the Statistica 10 software package. The type of questions and categories of answers contained in the questionnaire determined the qualitative nature of the variables analysed. For this reason, results of the interview were presented as numbers and percentages, and the nonparametric $\chi^{2}$ Pearson's independence test was used to assess the interdependencies between the studied features (Zeliaś, Pawełek and Wanat, 2002). The twocomponent concept of intellectual capital was adopted for the research, which is proposed, among others, by (Pietruszka-Ortyl, 2007). According to the author, intellectual capital can be divided into two elements: organizational capital and social capital.

Social capital determines the success of the enterprise, because it covers all the capabilities of individual employees of the organization to take advantage of development opportunities. It includes skills of effective interpersonal cooperation within groups and organizations, and also refers to trust between employees. It is formed by:

a) human capital, understood as knowledge, experience, skills, talents of employees and intellectual efficiency,

b) interpersonal relationships prevailing in the enterprise, such as attitudes, social roles, behavioural norms, and leadership.

The following measures were used to assess the level of social capital:

1. Human capital: knowledge, knowledge management, barriers in knowledge management, employees 'experience and skills, education, investments in employees (training, courses), creativity, developing the employees' skills, solutions enriching the qualification potential of employees.

2. Interpersonal relationships: help of superiors, lack of competition between employees caused by internal unhealthy competition.
The respondents were mostly lower-level employees (regardless of the enterprise's department; they constituted about $40 \%$ of the surveyed population), persons with relatively shorter seniority (about $2 / 3$ of respondents work in their company at most 8 years), as well as relatively young people (about $65 \%$ of the segment up to the age of 35 ). Among the respondents, a significant percentage - around $27 \%$ - were also those in managerial positions (directors or managers) and people with over 13 years of work experience (over $20 \%$ of respondents) and people aged 36-45 (about $1 / 4$ of the surveyed population). In total, 227 women and 173 men took part in the survey.

The research covered the largest number of small enterprises employing 10-49 employees; they constitute $53.0 \%$ of the surveyed population. Another 126 enterprises $(31.5 \%)$ can be classified as medium, employing between 50 and 249 employees. Large enterprises employing 250 people constitute $15.5 \%$ of the surveyed population. The smallest group was composed of micro-enterprises employing from 0 to 9 people, which constituted $20.5 \%$.

Over half of the surveyed enterprises operate without the aid of foreign capital. In 37 (9.2\%) enterprises, the share of foreign capital is small, not exceeding $25 \%$. A significant percentage $-12 \%$ - of the analysed enterprises is based mainly on foreign capital; its share exceeds $75 \%$ of the share of foreign capital.

Respondents from the vast majority of surveyed enterprises positively assess the financial condition of their enterprise - $178(44.5 \%)$ evaluate this element at a good level, and 102 enterprises (25.5\%) have a very good financial condition. Thirty per cent of respondents consider the financial possibilities of their enterprises as average or weak.

From the research and analyses carried out among 400 respondents from various enterprises of the Podkarpackie province, it results that the components of social capital of strategic importance affecting the development of enterprises are:

\footnotetext{
${ }^{1}$ Survey carried out in 2014/2015 in 400 selected enterprises of Podkarpackie province.
} 
1. Relations between employees

The research has shown that the majority of employees are satisfied with the employee relations prevailing in the enterprise, which also applies to the relations between employees and enterprise managers. Good relations between employees mean not only more comfortable work, but also measurable profits for the employer. Good communication improves the quality of work, facilitates problem solving and makes everyone more involved in the projects of the whole team and feel greater community with the enterprise. enterprise - it is the most valuable resource of the enterprise and a key success factor. The aim of investing in human capital in the surveyed enterprises is to provide human resources with the highest competencies, qualifications, skills, deriving job satisfaction and oriented to the implementation of strategic goals of the surveyed enterprises.

Forms of investing in human capital, i.e. employee training, conferences and courses, are carried out especially by medium and large companies; these forms of developing human capital in micro and small enterprises are used to a much lesser extent.

Table 1. Elements supporting employees' involvement in work

\begin{tabular}{|l|c|c|}
\hline Opinions & $N$ & $\%$ \\
\hline I work well with my colleagues and colleagues & 340 & 85.0 \\
\hline I know what accomplishments are expected of me & 329 & 82.2 \\
\hline I like my job & 329 & 82.2 \\
\hline I am proud that I work for this enterprise & 270 & 67.5 \\
\hline My competences/skills are useful for the enterprise & 356 & 89.0 \\
\hline I do not feel discriminated in an enterprise in any respect & 295 & 73.7 \\
\hline The enterprise creates the right working conditions for me & 292 & 73.0 \\
\hline
\end{tabular}

Source: own study based on research

\section{Investing in human capital}

Training, conferences, enterprise's participation in education costs, employee career plans, rewarding activities aimed at employee development - these are the main factors supporting the qualification potential of employees on the part of the enterprise. Human capital is the driving force of a market-oriented
By far, the most popular form of investing in broadening the knowledge of the enterprise's staff is employee training $-75.5 \%$ of responses.

3. Knowledge management supporting

Trainings supporting the development of employee competences, acquiring new entrepreneurial and

Table 2. Forms of investment in human capital

\begin{tabular}{|l|c|c|}
\hline Forms of investment & $N$ & $\%$ \\
\hline Employee training & 302 & 75.5 \\
\hline Conferences & 56 & 16.7 \\
\hline Courses & 145 & 36.2 \\
\hline Financial participation of the enterprise in the costs of employee education & 47 & 11.8 \\
\hline
\end{tabular}

Source: own study based on research 
Table 3. Enterprise involvement in knowledge management

\begin{tabular}{|l|c|c|}
\hline Opinions & $N$ & $\%$ \\
\hline Employees know where to look for specific information in the enterprise & 209 & 52.2 \\
\hline $\begin{array}{l}\text { Information about employees with specific knowledge is available at any time, anyone } \\
\text { can contact them and use their help }\end{array}$ & 146 & 36.5 \\
\hline There are no barriers to the use and exchange of knowledge between employees & 201 & 50.2 \\
\hline $\begin{array}{l}\text { Employees of the enterprise are encouraged to solve problems and share knowledge } \\
\text { with other employees }\end{array}$ & 106 & 26.5 \\
\hline $\begin{array}{l}\text { Exchange of knowledge takes place through informal contacts, conferences, meetings, } \\
\text { reports and notes }\end{array}$ & 116 & 29.0 \\
\hline $\begin{array}{l}\text { Employee knowledge is constantly developed and updated through training and } \\
\text { employee development programs }\end{array}$ & 147 & 36.7 \\
\hline The knowledge of employees leaving the enterprise is passed on to their successors & 85 & 21.2 \\
\hline
\end{tabular}

Source: own study based on research.

innovative employees as well as videoconferences are the most frequently indicated components of human capital supporting the knowledge management process in the surveyed companies. Knowledge management strategy is a way to improve the products or services provided.

The tool supporting the knowledge management in companies from the trade sector is the use of databases; in the industry and the sales department, it is Internet mail and video conferencing. E-mail is also one of the most important forms of communication with external entities in the industrial production. Industrial enterprises and the sales departments are dominated by employees with secondary education, while in service companies and the financial and insurance sector - they have the highest level of staff with higher education.

Improving the qualification potential of employees - education, knowledge of foreign languages and creativity of employees - this is the potential that the vast majority of employees of the Podkarpackie province enterprises have at their disposal. Therefore, the qualification potential of the employees must be developed and renewed, which in turn builds the organizational learning process. The goal of the surveyed enterprises should be to analyse and assess whether their resources, abilities and competences are a suf- ficient potential contributing to their more effective development.

Table 4 presents the financial results of economic entities of the Podkarpackie province in the analysed period - in detail, data on the revenues of enterprises, data on export sales, net and gross financial results and current assets of non-financial entities in the Podkarpackie province. The economic results included in the table also refer to financial data of a sample of enterprises in the Podkarpackie province (small, medium and large), participating in the survey, and conducting business in the period 2013-2015.

Good financial situation of the surveyed enterprises is in particular the effect of intellectual capital resources held by Podkarpackie enterprises, mainly social capital. In the majority of surveyed enterprises, the financial condition is assessed positively. Based on the access to financial reports during the conducted surveys, it was found that in the majority of surveyed enterprises, their financial condition has changed during the last years, i.e. the trend is developing. According to specialists working in accounting, this is the result of development of the enterprise, especially the increase in its value due to effective management of intellectual capital - including investing in human capital. 
Table 4. The amount of revenues, expenditures, sales and financial results of Podkarpackie province enterprises keeping accounting books in 2013-2015

\begin{tabular}{|c|l|c|c|c|}
\hline No & \multicolumn{1}{|c|}{ Specification } & 2013 & 2014 & 2015 \\
\hline 1 & Number of enterprises & 2212 & 2294 & 2284 \\
\hline 2 & Revenues from total activity (PLN million) & 88120.3 & 88830.5 & 100798.8 \\
\hline 3 & $\begin{array}{l}\text { Revenues from the sale of products, materials and goods } \\
\text { (PLN million) }\end{array}$ & 84610.5 & 85645.8 & 98601.6 \\
\hline 4 & Sales for export (PLN million) & 20623.7 & 21603.4 & 23107.6 \\
\hline 5 & $\begin{array}{l}\text { Financial result from the sale of products, materials and goods } \\
\text { (PLN million) }\end{array}$ & 3997.2 & 3924.3 & 4538.1 \\
\hline 6 & Net financial result (PLN million) & 4842.2 & 3834.1 & 3938.4 \\
\hline 7 & Gross financial result PLN million) & 5368.7 & 4334.5 & 4445.4 \\
\hline 8 & Current assets (PLN million) & 29833.1 & 29174.7 & 32155.4 \\
\hline 9 & Total investment expenditure (PLN million) & 3439.0 & 3354.2 & 3762.0 \\
\hline
\end{tabular}

Source: own study based on GUS (2014-2016).

To sum up, the most developed and used dimension of intellectual capital in the surveyed enterprises of the Podkarpackie province is social capital. Therefore, in the future, managers should look for the main source of success for Podkarpackie enterprises in that. Human capital is an important link in development of an enterprise - the employees who create new technologies, behaviours, norms, principles and values. Competences of the surveyed employees, new challenges faced by people employed in enterprises in various positions, forcing them to have more and more skills, new knowledge and competences, play a special role here.

The conducted research confirms that human capital and relations between employees, i.e. social capital, play a major role in enterprises. Analysing the components of intellectual capital, it can be clearly indicated that the structural capital as well as the capital of external relations are derived from human capital. There is a close causal relationship between the aforementioned capitals, because on the basis of human capital, the structural capital and the capital of external relations are generated in the surveyed enterprises.

In the surveyed enterprises, one of the components of intellectual capital, which enterprises use the most is knowledge of employees - knowledge is one of the most important sources of competitive advantage, because it determines development of the enterprise. The research shows that managers and employees of Podkarpackie province have large knowledge resources, due to which they help to increase the intellectual capital of enterprises. An example of this are numerous innovative enterprises that have been included in the study, which due to their knowledge are constantly developing, creating new jobs, introducing modern products, technologies, obtaining patents and certificates, as well as gaining new markets around the world.

Empirical verification of the impact of intellectual capital on the development of the surveyed enterprises provided information on the extent to which this hidden potential is used and helped to capture the intangible assets of enterprises that can grow and compete on regional market.

\section{CONCLUSIONS}

The Podkarpackie province is becoming more and more attractive economically from year to year for future investors. This is due to entrepreneurs, 
created economic zones that attract new enterprises as well as clusters operating in the region - e.g. Aviation Valley Cluster or Eastern Poland IT Company Cluster ${ }^{1}$. The survey conducted among 400 enterprise respondents of the Podkarpackie province are the confirmation that these enterprises consequently enhance by systematic development and strengthening their intellectual and producing potential, which in consequence improves their competitiveness and share on market.

The study material obtained from the conducted survey, statistical analysis of empirical data, and dependencies found, allowed for enhancing the view presented in the literature on the influence of the social capital on enterprise development. That information gives an opportunity to thoughts and perceptions about the directions of change that must be made in enterprises so that they can develop more effectively and increase their financial value.

In addition, knowledge about what constitutes the essence of social capital and how it is used in enterprises in the Podkarpackie province can give the opportunity to better manage, allocate resources in enterprises and control their attractiveness on the regional market.

Conclusions resulting from empirical research upon the level of social capital in Podkarpackie enterprises and its impact on the development of surveyed enterprises, may especially help future investors who want to invest their capital in Podkarpackie enterprises in the future - not only from the high chance sectors, but also into other sectors, that have been operating in Podkarpackie province for many years and are known all over the world.

\section{REFERENCES}

1. Dziura, B. (2016). Kapitał intelektualny a konkurencyjność przedsiębiorstw województwa podkarpackiego [Intellectual capital and the competitiveness of enterprises of Podkarpackie Province]. Doctorial Thesis, Uniwersytet Technologiczno-Humanistyczny, Radom.

2. Gagacka, M. (2008., Kapitał ludzki a innowacyjność [Human capital and innovation]. In: Głąbicka, K., Kalotka, J. (ed.) Zbadanie potencjału innowacyjnego subregionu radomskiego [Investigation of the innovative potential of the Radom subregion]. Raport z badań, etap I - Diagnoza, Radom, p. 17.

3. GUS Wrocław (2014-2016). Bilansowe wyniki finansowe podmiotów gospodarczych, [Balance sheet financial results of business entities]. Informacje i Opracowania Statystyczne. Dział Wydawnictw Statystycznych, Warszawa.

4. Marshall, A. (1965). Principles of Economics. Londpn.

5. Pietruszka-Ortyl, A. (2007). Kapitał intelektualny organizacji [The intellectual capital of the organization]. In: Mikuła, B., Pietruszka-Ortyl, A., Potocki A. (eds.) Podstawy zarządzania przedsiębiorstwami w gospodarce opartej na wiedzy [Basics of business management in a knowledge-based economy]. Difin, Warszawa, pp. 80-83.

6. Przybysz, J. (2011). Kapitał społeczny a poziom innowacyjności małych średnich przedsiębiorstw [Social capital and the level of innovation of small medium enterprises] Optimum, Studia Ekonomiczne, 2 (50), p. 208.

7. Raport o kapitale intelektualnym Polski [Report on intellectual capital of Poland] (2008). Warszawa.

8. Ujwary-Gil, A. (2009). Kapitał intelektualny a wartość przedsiębiorstwa [Intellectual capital and the value of the enterprise]. Beck, Warszawa.

9. Zeliaś, A., Pawełek, B., Wanat, S. (2002). Metody statystyczne [Statistical methods]. PWE, Warszawa.

${ }^{1}$ The TNS Polska study shows that economic attractiveness of the Podkarpackie province increased by $10 \%$ compared to the situation from 5 years ago. Data on 30 December 2015. 